\title{
PENGARUH VARIETAS KACANG TANAH (Arachis hypogaea L.) DAN RASIO GULA AREN : GULA PASIR TERHADAP KARAKTERISTIK ENTING-ENTING GETI
}

\section{The Effect of Groundnut (Arachis hypogaea L.) Varieties and Palm (Arenga pinnata Merr.) Sugar to Refined Cane Sugar Ratio on Enting-Enting Geti Characteristics}

\author{
Nanda Triachdiani*, Erni Sofia Murtini \\ Jurusan Teknologi Hasil Pertanian, FTP Universitas Brawijaya Malang \\ Jl. Veteran, Malang 65145 \\ *Penulis Korespondensi, Email: nandatriachdiani@gmail.com
}

\begin{abstract}
ABSTRAK
Produk enting-enting geti yang beredar di pasar saat ini masih memiliki karakteristik yang berbeda-beda. Karakteristiknya dapat ditentukan oleh penggunaan jenis kacang serta jenis dan rasio gula pada proses pembuatannya. Tujuan penelitian ini adalah untuk mengetahui pengaruh perbedaan varietas kacang tanah dan rasio gula aren : gula pasir terhadap karakteristik fisik, kimia, dan organoleptik dari produk enting-enting geti. Metode yang digunakan adalah RAK Faktorial dengan dua faktor yaitu varietas kacang tanah dan rasio gula aren : gula pasir. Data dianalisis dengan ANOVA dilanjutkan uji lanjut BNT atau DMRT dengan taraf kepercayaan 95\%. Varietas kacang tanah berpengaruh nyata pada nilai kemerahan $\left(a^{*}\right)$. Rasio gula aren : gula pasir berpengaruh nyata pada daya patah, nilai kecerahan $\left(L^{*}\right)$, nilai kekuningan $\left(b^{*}\right)$, dan kadar air. Interaksi kedua faktor berpengaruh nyata pada daya patah. Enting-enting geti perlakuan terbaik didapatkan pada produk dengan varietas kacang tanah Sudan dan rasio gula aren : gula pasir (1:1).
\end{abstract}

Kata kunci: Enting-enting geti, Gula aren, Gula pasir, Kacang tanah

\section{ABSTRACT}

Nowadays, the characteristics of enting-enting geti on the market are still varied. The presence of that diversity is due to the bean types and the sugar proportion used. This study aims to observe the effects delivered by different groundnut varieties and palm sugar-torefined sugar ratio, to the characteristics of enting-enting geti. RBD was performed applying two factors: groundnut varieties and palm sugar-to-refined sugar ratio. The data were analyzed using ANOVA followed by LSD or DMRT tests with a 95\% confidence level. Based on the results, it is evident that groundnut varieties give a significant effect on the redness value $\left(a^{*}\right)$. Significant effects are also denoted by the palm sugar-to-refined sugar ratio on cracking ability, brightness $\left(L^{*}\right)$, yellowish value $\left(b^{*}\right)$, and water content, and by the interaction of both factors on cracking ability. Sudanese varieties with 1:1 palm sugar-to-refined sugar ratio made up the best treatment.

Keywords. Enting-enting geti, Groundnut, Palm sugar, Refined cane sugar

\section{PENDAHULUAN}

Enting-enting geti, makanan ringan khas Tulungagung, terbuat dari campuran biji wijen, kacang tanah, gula merah dan gula pasir yang dipanaskan kemudian dicetak (Januariani, 2018). Enting-enting geti memiliki karakteristik yang khas dalam aspek warna, 
aroma, tekstur dan rasa. Hingga saat ini produk enting-enting geti yang beredar di pasaran masih memiliki karakteristik yang berbeda antar rumah produksi. Perbedaan karakteristik ini dapat dipengaruhi oleh formulasi dan proses produksi yang berbeda dari setiap rumah produksi enting-enting geti (Mustaniroh et al., 2019). Beberapa faktor yang mempengarui karakteristik enting-enting geti yaitu jenis kacang tanah, rasio antara kacang dengan gula, jenis gula dan rasio antar gula. Hingga saat ini, belum terdapat standar mutu untuk produk enting-enting geti, sehingga pada penelitian ini standar mutu yang digunakan adalah standar mutu.enting-enting kacang gepuk (SNI 01-4034-1996).

Kacang tanah (Arachis hypogaea L.) merupakan salah satu jenis tanaman legume terpenting dalam dunia pangan karena merupakan sumber minyak dan protein yang baik bagi manusia (Abbas et al., 2018). Varietas kacang tanah yang dijadikan sebagai bahan baku enting-enting geti masih tidak diketahui dengan pasti karena umumnya UKM hanya membeli kacang tanah yang tersedia di pasar lokal. Padahal terdapat banyak sekali varietas kacang tanah dan penggunaan varietas kacang tanah yang berbeda akan dapat mempengaruhi kualitas sensori dari produk yang dihasilkan (Dhamsaniya et al., 2012). Beberapa varietas kacang tanah yang banyak dipasarkan di Jawa Timur adalah kacang tanah var. Tuban, Sudan dan Gajah.

Tabel 1. Perbedaan antara Kacang Tanah var. Tuban, Sudan dan Gajah

\begin{tabular}{|c|c|c|c|}
\hline Keterangan & Tuban ${ }^{\left.a^{\star}\right)}$ & Sudan ${ }^{\left.b^{\star}\right)}$ & Gajah $^{\left.\mathrm{a}^{*}\right)}$ \\
\hline Asal & $\begin{array}{c}\text { Seleksi galur dan massa } \\
\text { dari populasi varietas } \\
\text { lokal Tuban asal } \\
\text { Semarang }\end{array}$ & $\begin{array}{c}\text { Produksi Negara } \\
\text { Bagian Darfur Selatan, } \\
\text { Sudan }\end{array}$ & $\begin{array}{l}\text { Seleksi keturunan } \\
\text { persilangan Schwarz- } \\
21 \text { Spanish 18-38 }\end{array}$ \\
\hline Kadar protein (\%) & $21_{-}, 4$ & $28=97$ & 29 \\
\hline Kadar lemak (\%) & 42.5 & 47. 94 & 48 \\
\hline
\end{tabular}

Sumber: $a^{*}$ ) Balai Penelitian Tanaman Aneka Kacang dan Umbi (2016), b*) Abdualrahman (2013)

Pada umumnya dalam proses pembuatan enting-enting geti digunakan jenis gula pasir saja atau kombinasi dari gula pasir dan gula aren. Penggunaan gula aren dapat menghasilkan citarasa yang khas gula aren pada produk enting-enting geti (Erlienawati et al., 2017). Penambahan gula pasir yang terlalu sedikit akan menghasilkan produk enting-enting yang kurang manis dan mudah hancur, begitupun sebaliknya jika penambahan gula pasir terlalu banyak akan menghasilkan produk enting-enting yang terlalu manis dan keras (Ismayasari, Wahyuningsih dan Paramita, 2014). Maka dari itu, perlu diketahui rasio gula aren : gula pasir yang dapat menghasilkan produk enting-enting geti dengan karakteristik terbaik.

Tabel 2. Perbedaan antara Gula Aren dan Gula Pasir

\begin{tabular}{|c|c|c|}
\hline Keterangan & Gula Aren & Gula Pasir \\
\hline Kadar Protein (\%) & $0^{\left.a^{*}\right)}$ & $0^{\left.\mathrm{a}^{*}\right)}$ \\
\hline Kadar Lemak (\%) & $\left.0 .-11 a^{*}\right)$ & $0^{\left.a^{*}\right)}$ \\
\hline Gula Pereduksi (\%) & $\left.2,89 b^{*}\right)$ & - \\
\hline Sukrosa $(\%)$ & $87 .=83^{\left.b^{*}\right)}$ & - \\
\hline Total Gula (\%) & - & $99_{-=-3} 8^{\left.c^{*}\right)}$ \\
\hline
\end{tabular}

Oleh karena itu, penelitian ini dilakukan untuk mengetahui pengaruh penggunaan beberapa varietas kacang tanah (Tuban, Sudan dan Gajah) serta rasio gula aren : gula pasir $(1: 1,2: 1$, dan 3:1) terhadap karakteristik fisik, kimia, dan organoleptik enting-enting geti sehingga dapat ditentukan enting-enting geti perlakuan terbaik.

\section{BAHAN DAN METODE}

\section{Bahan}


Dalam pembuatan enting-enting geti diperlukan bahan-bahan berupa kacang tanah (varietas Tuban, Sudan, dan Gajah), gula pasir, gula aren, biji wijen putih yang telah disosoh dan margarin (Blueband). Sedangkan dalam analisis diperlukan tablet Kjedahl, asam sulfat pekat $\left(\mathrm{H}_{2} \mathrm{SO}_{4}\right)$, petroleum eter, akuades, $\mathrm{NaOH} 30 \%$, asam borat $4 \%, \mathrm{HCl} 0,1 \mathrm{~N}$, reagen Anthrone, $\mathrm{CaCO}_{3}, \mathrm{~Pb}$-asetat, $\mathrm{Na}$-oksalat, indikator metil merah, dan indikator fenolftalein.

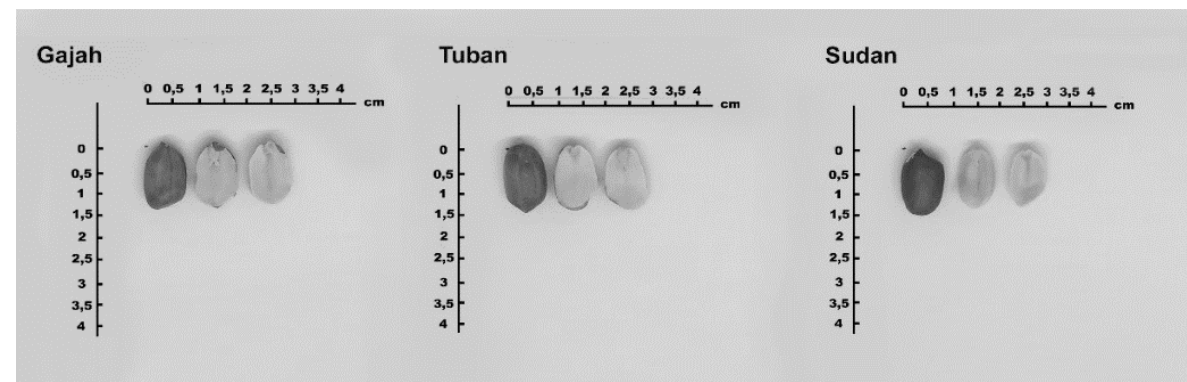

Gambar 1. Kenampakan Kacang Tanah (Dokumentasi mandiri, 2020).

\begin{abstract}
Alat
Alat yang digunakan dalam proses pembuatan enting-enting geti diantaranya adalah kompor (Panasonic), wajan, pengaduk kayu, alat penumbuk kayu, timbangan digital, loyang, wadah, sendok, pisau, saringan 10 mesh dan cetakan kayu. Sedangkan alat yang digunakan untuk analisis diantaranya adalah oven listrik (Memmert), kompor listrik (Maspion), ekstraktor soxhlet, unit distilasi kjeldahl (Buchi), penangas air(Mammert), desikator (Simax), labu lemak, labu kjehdahl (Buchi), lemari asam, buret, timbangan analitik, vortex, statif, benang wol, CT3 Texture Analyzer (Brookfield Engineering Labs Inc, USA) dengan software TexturePro CT $\mathrm{V} 14$, color reader, kertas saring Whatman dan glassware yang mendukung.
\end{abstract}

\title{
Desain Penelitian
}

Penelitian dilakukan dengan metode RAK Faktorial menggunakan 2 faktor. Faktor pertama adalah varietas kacang tanah (Tuban, Sudan dan Gajah), sedangkan faktor kedua adalah rasio gula aren : gula pasir $(1: 1,2: 1$, dan $3: 1)$. Data dianalisis dengan uji ANOVA dan dilanjutkan uji BNT atau DMRT apabila terdapat interaksi dengan taraf kepercayaan 95\% $(\langle=0.05)$. Data hasil uji organoleptik diperoleh dengan metode Hedonic Scale Scoring, kemudian dianalisis dengan uji Friedman. Penentuan perlakuan terbaik dilakukan dengan menggunakan metode Multiple Attribute.

\section{Tahapan Penelitian \\ Penyangraian dan Pemisahan Kulit Ari Kacang Tanah}

Kacang tanah disangrai pada wajan dengan suhu $100^{\circ} \mathrm{C}$ selama 15 menit hingga kulit ari berwarna coklat gelap. Kemudian dipisahkan antara kulit ari dengan biji kacang tanah. Lalu ditumbuk dan disaring dengan saringan 10 mesh. Kacang tanah tumbuk kemudian disangrai kembali pada suhu $100^{\circ} \mathrm{C}$ selama 15 menit hingga berwarna coklat keemasan.

\section{Penyangraian Biji Wijen}

Biji wijen disangrai pada wajan dengan suhu $100^{\circ} \mathrm{C}$ selama 10 menit hingga berwarna kulit.

\section{Pembuatan Enting-Enting Geti}

Kacang tanah dan biji wijen ditimbang masing-masing sebanyak $70 \mathrm{~g}$ dan $5 \mathrm{~g}$. Gula ditimbang sebanyak $70 \mathrm{~g}$ dengan rasio gula aren : gula pasir 1:1, 2:1 dan 3:1. Margarin ditimbang sebanyak $6.25 \mathrm{~g}$. Kemudian margarin dipanaskan hingga mencair. Setelah itu ditambahkan gula aren dan gula pasir sesuai rasio. Lalu dipanaskan pada suhu $100^{\circ} \mathrm{C}$ selama 3 menit hingga mencair dan mengental dengan diaduk sesekali. Setelah mengental ditambahkan kacang tanah dan biji wijen. Diaduk hingga merata dan dituang ke dalam loyang yang telah diolesi dengan margarin. Enting-enting geti kemudian dipotong ukuran $5 \times 2 \times 1 \mathrm{~cm}$. 


\section{Metode}

Analisis enting-enting geti meliputi analisis kimia (kadar air, kadar protein, kadar lemak, dan total gula), dan analisis fisik (daya patah dan warna). Uji hedonik dilakukan dengan menyajikan 9 sampel enting-enting geti sesuai perlakuan, kepada 85 panelis tidak terlatih. Parameter yang diujikan adalah parameter warna, aroma, rasa, tekstur dan overall liking atau kesukaan secara keseluruhan. Penilaian dilakukan dengan sistem scoring skala 1-9 dengan rentang amat sangat tidak suka hingga amat sangat suka.

\section{Prosedur Analisis}

\section{Kadar Air (AOAC, 2006)}

Sampel ditimbang 2 gram dan dimasukkan ke dalam cawan alumunium yang telah dikeringkan dan diketahui bobotnya. Sampel dikeringkan dalam oven suhu $105^{\circ} \mathrm{C}$ selama 5 jam lalu ditimbang. Pengeringan diulang hingga diperoleh bobot konstan.

$$
\text { Kadar air }(\%)=\frac{\text { bobot sampel awal-bobot sampel setelah dikeringkan }}{\text { bobot sampel awal }} \times 100 \%
$$

\section{Kadar Protein Metode Kjedahl (AOAC, 2005)}

Sampel ditimbang 1 gram dan didestruksi hingga berubah menjadi jernih selama 3 jam. Sampel kemudian didestilasi dengan ditambahkan $\mathrm{NaOH} \mathrm{40 \% .} \mathrm{Gas} \mathrm{ammonia} \mathrm{yang} \mathrm{keluar}$ akan ditampung pada larutan asam borat 3\%. Sampel dititrasi dengan $\mathrm{HCl} 0.1 \mathrm{~N}$ yang diawali dengan blanko. Penetapan blanko dilakukan dengan langkah yang sama tanpa menggunakan sampel.

$$
\begin{gathered}
\text { Kadar N }(\%)=\frac{\text { volume } \mathrm{HCl}(\text { sampel-blanko }) \times N \mathrm{HCl} \times 14,007 \times 100}{m g \text { sampel }} \\
\text { Kadar Protein }(\%)=\% \mathrm{~N} \times \text { faktor konversi }
\end{gathered}
$$

\section{Kadar Lemak (AOAC, 2005)}

Sampel ditimbang 2 gram kemudian sampel dihaluskan dan dibungkus dengan kertas saring serta ditutup kapas bebas lemak. Kemudian dilakukan ekstraksi dengan soxhlet selama 5 jam. Pemisahan pelarut dengan dengan diuapkan, lalu labu lemak dikeringkan pada oven suhu 105ㅇ hingga diperoleh berat konstan. Berat residu pada labu lemak dinyatakan sebagai berat lemak.

$$
\text { Kadar lemak }(\%)=\frac{\text { berat lemak }(g)}{\text { berat } \operatorname{sampel}(g)} \times 100 \%
$$

\section{Total Gula (Apriyanto, 1994)}

Membuat kurva standar terlebih dahulu. Ditimbang $5.8 \mathrm{~g}$ sampel dan dimasukkan ke dalam erlenmeyer lalu ditambahkan akuades dan $\mathrm{CaCO}_{3}$ hingga kertas lakmus menjadi biru. Sampel dipanaskan, setelah itu diencerkan. Ditambahkan $3.5 \mathrm{~g} \mathrm{~Pb}$-asetat, $0.1 \mathrm{~g} \mathrm{Na}$-oksalat dan akuades pada sampel. Selanjutnya sampel disaring dan diencerkan kembali. Sampel dihomogenkan dengan vortex lalu diambil $1 \mathrm{ml}$ dan ditambahkan $5 \mathrm{ml}$ reagen anthrone. Tabung ditutup lalu dipanaskan hingga mendidih. Masing-masing diukur absorbansinya pada panjang gelombang $630 \mathrm{~nm}$. Kemudian nilai absorbansi yang diperoleh dimasukkan ke persamaan kurva standar sehingga didapatkan konsentrasi gula.

\section{Tekstur (Daya Patah) (Modifikasi AACC, 2000)}

Daya patah diukur dengan dengan menggunakan universal testing machine dengan prinsip penetrasi dan menggunakan cone lancip. Hasil pengukuran daya patah dinyatakan dalam bentuk Newton (N). Penetrasi dilakukan pada titik tengah produk dan dihasilkan nilai daya patah produk. 


\section{Warna dengan Color Reader (Yuwono dan Susanto, 1998)}

Disiapkan sampel yang akan dianalisis ke dalam plastik bening. Dihidupkan color reader. Diatur tombol pembacaan $L^{*} a * b$ color space $L^{*} c^{*} h$, kemudian ditekan tombol target. Hasil pembacaan dicatat dan diukur warnanya

\section{HASIL DAN PEMBAHASAN}

\section{Kadar Air}

Perbedaan rasio gula aren : gula pasir memberikan pengaruh yang nyata terhadap kadar air produk enting-enting geti. Tabel 4 menunjukkan bahwa semakin tinggi rasio gula aren yang digunakan maka akan semakin tinggi pula kadar air yang terdapat pada produk enting-enting. Hal tersebut dapat diakibatkan oleh standar kandungan air dari gula palem cetak di Indonesia yang cukup tinggi yaitu sebesar maksimal 10\% (BSN, 1995). Menurut USDA (2019) dalam Food Data Central ID 343930, kadar air pada gula pasir yaitu sebesar $0_{-5}, 02 \%$. Penggunaan gula aren akan mempengaruhi kadar air pada produk enting-enting geti menjadi lebih tinggi dibandingkan dengan produk enting-enting tanpa menggunakan gula aren. Berdasarkan SNI 01-4034-1996, standar kandungan kadar air maksimal yang ditentukan untuk produk enting-enting gepuk yaitu sebesar 3.5\% (b/b) (BSN, 1996). Hal ini menunjukkan bahwa produk enting-enting geti dengan perbedaan varietas kacang tanah dan rasio gula aren : gula pasir masih belum memenuhi standar yang berlaku di Indonesia. Tingginya kadar air yang terdapat pada produk enting-enting geti dapat diakibatkan oleh penggunaan gula aren pada proses pembuatannya.

Rerata kadar air produk enting-enting geti akibat perbedaan rasio gula aren : gula pasir disajikan pada Tabel 3.

Tabel 3. Rerata Kadar Air Produk Enting-Enting Geti Akibat Perbedaan Rasio Gula Aren : Gula Pasir

\begin{tabular}{ccc} 
Rasio Gula Aren : Gula Pasir & Kadar Air (\%) & BNT 5\% \\
\hline $1: 1$ & $10.56 \pm 0.16^{\mathrm{a}}$ & \\
$2: 1$ & $11.77 \pm 0.38^{\mathrm{b}}$ & 1.01 \\
$3: 1$ & $12.45 \pm 0.30^{\mathrm{b}}$ & \\
\hline
\end{tabular}

\section{Kadar Protein}

Perbedaan varietas kacang tanah dan rasio gula aren : gula pasir tidak memberikan pengaruh yang nyata terhadap kadar protein produk enting-enting geti. Hal tersebut dapat diakibatkan oleh kadar protein pada ketiga kacang tanah yang digunakan tidak berbeda jauh dan kedua jenis gula yang digunakan tidak mengandung atau mengandung sangat sedikit kandungan protein. Selain itu, tingginya suhu yang digunakan dalam proses pemasakan dapat menyebabkan kemungkinan terjadinya kerusakan protein sehingga kadar protein dalam bahan pangan menjadi berkurang (Sundari et al., 2015). Choong et al. (2016) menyatakan bahwa gula pasir dan gula aren memiliki kandungan protein sebesar $0 \%$. Berdasarkan $\mathrm{SNI}$ 01-4034-1996, standar kandungan kadar protein minimal yang ditentukan untuk pada produk enting-enting gepuk yaitu sebesar 16\% (BSN, 1996). Hal ini menunjukkan bahwa produk enting-enting geti dengan penggunaan varietas kacang tanah dan rasio gula aren : gula pasir ini masih belum memenuhi standar yang berlaku di Indonesia.

\section{Kadar Lemak}

Perbedaan varietas kacang tanah dan rasio gula aren : gula pasir tidak memberikan pengaruh yang nyata terhadap kadar lemak produk enting-enting geti. Hal tersebut dapat diakibatkan oleh kadar lemak pada ketiga kacang tanah yang digunakan tidak berbeda jauh dan kedua jenis gula yang digunakan tidak mengandung atau mengandung sangat sedikit kandungan lemak. Kandungan lemak dalam kacang tanah dapat mengalami penurunan 
akibat proses penyangraian (Amaluddin dan Yuwono, 2015). Selama proses penyangraian lemak dapat mengalami perubahan bentuk menjadi cair sehingga dapat keluar dari jaringan biji kacang tanah. Mora-Escobedo et al. (2015) menyatakan bahwa pada biji dari beberapa varietas kacang tanah mengandung asam lemak tidak jenuh lebih tinggi dibandingkan dengan asam lemak jenuh. Hal tersebut membuat titik leleh lemak dalam biji kacang tanah cukup rendah. Choong et al. (2016) menyatakan bahwa gula pasir memiliki kandungan lemak sebesar $0 \%$ sedangkan gula aren memiliki kandungan lemak sebesar $0.11 \%$. Berdasarkan SNI 01-4034-1996, standar kandungan kadar lemak maksimal yang ditentukan untuk pada produk enting-enting gepuk yaitu sebesar 30\% (BSN, 1996). Hal ini menunjukkan bahwa produk enting-enting geti dengan penggunaan varietas kacang tanah dan rasio gula aren : gula pasir telah memenuhi standar yang berlaku di Indonesia.

\section{Total Gula}

Perbedaan varietas kacang tanah dan rasio gula aren : gula pasir tidak memberikan pengaruh yang nyata terhadap total gula produk enting-enting geti. Hal tersebut dapat diakibatkan oleh total gula pada ketiga kacang tanah dan kedua jenis gula yang digunakan tidak berbeda jauh. Berdasarkan Food Data Central ID 343930, kandungan total gula pada gula pasir sebesar 99.8\% (USDA, 2019). Berdasarkan Iskandar et al. (2015), rata-rata kandungan gula pereduksi dan sukrosa pada beberapa gula aren cetak masing-masing sebesar $2.89 \%$ dan $87.83 \%$. Sehingga dapat dikatakan rata-rata kandungan total gula untuk beberapa gula aren cetak sebesar $90.72 \%$. Selain itu, hasil ini juga dapat diakibatkan oleh rentang rasio yang digunakan antara perlakuan kurang signifikan. Berdasarkan SNI 01-40341996, standar kandungan sakarosa yang ditentukan untuk produk enting-enting gepuk yaitu sebesar 40-50\% (BSN, 1996). Hal ini menunjukkan bahwa beberapa produk enting-enting geti dengan penggunaan varietas kacang tanah dan rasio gula aren : gula pasir telah memenuhi standar dan beberapa lainnya belum memenuhi standar yang berlaku di Indonesia. Rerata kadar protein, kadar lemak dan total gula produk enting-enting geti disajikan pada Tabel 4.

Tabel 4. Rerata Kadar Protein, Kadar Lemak, dan Total Gula Produk Enting-Enting Geti

\begin{tabular}{ccccc}
\hline $\begin{array}{c}\text { Varietas } \\
\text { Kacang Tanah }\end{array}$ & $\begin{array}{c}\text { Rasio Gula } \\
\text { Aren : Gula } \\
\text { Pasir }\end{array}$ & $\begin{array}{c}\text { Kadar Protein } \\
(\%)\end{array}$ & $\begin{array}{c}\text { Kadar Lemak } \\
(\%)\end{array}$ & Total Gula (\%) \\
\hline \multirow{3}{*}{ Tuban } & $1: 1$ & $10.81 \pm 0.92$ & $26.70 \pm 5.16$ & $36.59 \pm 16.00$ \\
& $2: 1$ & $9.85 \pm 0.44$ & $25.91 \pm 4.03$ & $30.31 \pm 23.43$ \\
Sudan & $3: 1$ & $8.89 \pm 1.80$ & $25.32 \pm 3.20$ & $33.89 \pm 17.65$ \\
& $1: 1$ & $12.23 \pm 1.06$ & $24.83 \pm 0.93$ & $37.85 \pm 14.22$ \\
Gajah & $2: 1$ & $6.91 \pm 8.59$ & $25.58 \pm 0.12$ & $40.60 \pm 8.88$ \\
& $3: 1$ & $6.58 \pm 9.05$ & $24.55 \pm 1.35$ & $44.82 \pm 2.19$ \\
& $1: 1$ & $7.03 \pm 9.25$ & $25.44 \pm 0.11$ & $40.62 \pm 10.31$ \\
& $2: 1$ & $12.91 \pm 0.92$ & $23.15 \pm 3.36$ & $51.33 \pm 6.29$ \\
& $3: 1$ & $13.34 \pm 0.32$ & $26.79 \pm 1.77$ & $39.06 \pm 10.34$ \\
\hline
\end{tabular}

\section{Daya Patah}

Berdasarkan Tabel 5. semakin tinggi rasio gula aren yang digunakan maka akan semakin tinggi pula daya patah pada produk enting-enting. Hal tersebut dapat diakibatkan oleh semakin tingginya kandungan gula reduksi yang terdapat pada enting-enting geti. Fruktosa dan glukosa dapat mengalami proses karamelisasi pada suhu yang lebih rendah dibandingkan dengan sukrosa, sehingga fruktosa dan glukosa akan mengalami proses karamelisasi lebih cepat daripada sukrosa dan membentuk tekstur yang keras (Bayline et al., 2018). Selain itu, reaksi Maillard lanjutan selama proses penyimpanan juga mungkin terjadi. Zhou, et al (2013) menyatakan bahwa reaksi Maillard dapat menyebabkan terjadinya glikasi dan agregasi molekul protein sehingga menyebabkan 
berkurangnya jumlah kandungan fruktosa yang berfungsi sebagai plasticizer dan membentuk tekstur yang keras. Rerata daya patah produk enting-enting geti akibat interaksi perbedaan varietas kacang tanah dan rasio gula aren : gula pasir disajikan pada Tabel 6 .

Tabel 5. Rerata Daya Patah Produk Enting-Enting Geti Akibat Interaksi Perbedaan Varietas Kacang Tanah dan Rasio Gula Aren : Gula Pasir

\begin{tabular}{cccc}
\hline \multirow{2}{*}{ Varietas Kacang Tanah } & $\begin{array}{c}\text { Rasio Gula Aren : Gula } \\
\text { Pasir }\end{array}$ & $\begin{array}{c}\text { Rerata Daya } \\
\text { Patah (N) }\end{array}$ & DMRT 5\% \\
\hline \multirow{3}{*}{ Tuban } & $1: 1$ & $12.70 \pm 0.99^{\mathrm{a}}$ & 18.15 \\
& $2: 1$ & $37.87 \pm 17.39^{\mathrm{bc}}$ & 18.94 \\
\multirow{3}{*}{ Sudan } & $3: 1$ & $50.50 \pm 10.61^{\mathrm{c}}$ & 19.40 \\
& $1: 1$ & $13.00 \pm 0.99^{\mathrm{a}}$ & 19.69 \\
\multirow{3}{*}{ Gajah } & $2: 1$ & $24.75 \pm 1.77^{\mathrm{ab}}$ & 19.87 \\
& $3: 1$ & $39.65 \pm 2.90^{\mathrm{bc}}$ & 19.99 \\
& $1: 1$ & $22.80 \pm 5.09^{\mathrm{ab}}$ & 20.06 \\
& $2: 1$ & $30.10 \pm 0.57^{\mathrm{ab}}$ & 20.11 \\
\hline
\end{tabular}

\section{Nilai Kecerahan $\left(L^{*}\right)$}

Berdasarkan Tabel 6. semakin tinggi rasio gula aren yang digunakan maka akan semakin tinggi pula nilai kecerahan $\left(L^{*}\right)$ produk enting-enting. Hal tersebut diakibatkan oleh warna asli gula aren yang coklat gelap sehingga apabila semakin banyak gula aren yang digunakan maka akan menurunkan nilai kecerahan $\left(\mathrm{L}^{*}\right)$ yang dihasilkan pada produk akhir enting-enting geti. Menurut Choong et al. (2016), pada dasarnya gula aren memiliki warna yang coklat kekuningan hingga coklat. Warna yang terbentuk ini dapat dipengaruhi oleh tipe bahan baku yang digunakan, proses pemanasan (suhu dan waktu pemanasan) serta proses kimia yang terjadi. Penggunaan suhu yang tinggi dapat meningkatkan jumlah gula reduksi yang bereaksi dengan asam amino (reaksi Maillard) sehingga menghasilkan pigmen coklat / melanoidin yang berperan dalam membentuk warna coklat pada hasil akhir produk gula aren (Naknean dan Meenune, 2011).

Tabel 6. Rerata Nilai Kecerahan $\left(L^{*}\right)$, dan Nilai Kekuningan $\left(b^{*}\right)$ Produk Enting-Enting Geti Akibat Perbedaan Rasio Gula Aren : Gula Pasir

\begin{tabular}{ccc}
\hline $\begin{array}{c}\text { Rasio Gula Aren : } \\
\text { Gula Pasir }\end{array}$ & Nilai Kecerahan $\left(\mathbf{L}^{\star}\right)$ & Nilai Kekuningan $\left(\mathbf{b}^{\star}\right)$ \\
\hline $1: 1$ & $132.52 \pm 8.11^{\mathrm{b}}$ & $55.47 \pm 1.87^{\mathrm{c}}$ \\
$2: 1$ & $123.83 \pm 5.65^{\mathrm{a}}$ & $52.10 \pm 1.95^{\mathrm{b}}$ \\
$3: 1$ & $120.97 \pm 2.71^{\mathrm{a}}$ & $48.15 \pm 2.59^{\mathrm{a}}$ \\
\hline BNT 5\% & 6.99 & 3.07
\end{tabular}

\section{Nilai Kemerahan ( $\left.a^{*}\right)$}

Tabel 7. menunjukkan bahwa nilai kemerahan $\left(a^{*}\right)$ tertinggi terdapat pada produk entingenting geti yang menggunakan kacang tanah varietas Tuban dan terendah pada produk enting-enting geti yang menggunakan kacang tanah varietas Gajah. McDaniel et al. (2012) menyebutkan bahwa perubahan warna pada kacang tanah sangrai dapat dipengaruhi oleh suhu dan waktu penyangraian yang digunakan serta kandungan gula dan protein yang terdapat pada kacang tanah itu sendiri. Kandungan gula dengan keberadaan asam amino dalam kacang tanah akan memicu terjadinya reaksi Maillard. Rerata nilai kemerahan $\left(\mathrm{a}^{*}\right)$ produk enting-enting geti akibat perbedaan varietas kacang tanah disajikan pada Tabel 7. 
Pengaruh Varietas Kacang Tanah dan Rasio Gula Aren : Gula Pasir - Triachdiani, dkk Jurnal Pangan dan Agroindustri Vol. 9 No.2: 100-110, April 2021

Tabel 7. Rerata Nilai Kemerahan ( $\left.a^{*}\right)$ Produk Enting-Enting Geti Akibat Perbedaan Varietas Kacang Tanah

\begin{tabular}{ccc}
\hline Varietas Kacang Tanah & Nilai Kemerahan $\left(\mathbf{a}^{*}\right)$ & BNT 5\% \\
\hline Tuban & $12.63 \pm 0.73^{\mathrm{b}}$ & \\
Sudan & $10.32 \pm 0.52^{\mathrm{a}}$ & 1.53 \\
Gajah & $9.38 \pm 1.18^{\mathrm{a}}$ & \\
\hline
\end{tabular}

\section{Nilai Kekuningan $\left(b^{\star}\right)$}

Berdasarkan Tabel 6 . semakin tinggi rasio gula aren yang digunakan maka akan semakin rendah nilai kekuningan $\left(b^{*}\right)$ produk enting-enting. Hal tersebut diakibatkan oleh gula aren yang memiliki warna yang coklat kekuningan hingga coklat (Choong et al., 2016). Warna yang terbentuk ini dapat dipengaruhi oleh tipe bahan baku yang digunakan, proses pemanasan (suhu dan waktu pemanasan) serta proses kimia yang terjadi. Penggunaan suhu yang tinggi dapat meningkatkan jumlah gula reduksi yang bereaksi dengan asam amino (reaksi Maillard) sehingga menghasilkan pigmen coklat / melanoidin yang berperan dalam membentuk warna coklat pada hasil akhir produk gula aren (Naknean dan Meenune, 2011). Pada penelitian ini, gula pasir hanya dipanaskan hingga menjadi larutan gula pasir tanpa warna sehingga semakin rendah rasio gula aren yang digunakan maka akan semakin terang pula warna coklat yang terbentuk pada produk enting - enting geti. Rerata nilai kecerahan $\left(L^{*}\right)$ dan nilai kekuningan $\left(b^{*}\right)$ produk enting-enting geti akibat perbedaan rasio gula aren : gula pasir disajikan pada Tabel 6.

\section{Uji Organoleptik}

Uji organoleptik dilakukan pada ke-9 perlakuan enting-enting geti dengan menggunakan 85 orang panelis berusia 19-23 tahun yang berstatus mahasiswa. Data hasil kemudian dianalisis dengan menggunakan metode Friedman yang ditunjukkan pada Tabel 8.

Tabel 8. Rerata Peringkat Uji Friedman Seluruh Parameter Organoleptik

\begin{tabular}{ccccccc}
\hline $\begin{array}{c}\text { Varietas } \\
\text { Kacang } \\
\text { Tanah }\end{array}$ & $\begin{array}{c}\text { Rasio } \\
\text { Gula } \\
\text { Aren : } \\
\text { Gula } \\
\text { Pasir }\end{array}$ & $\begin{array}{c}\text { Peringkat } \\
\text { Warna }\end{array}$ & $\begin{array}{c}\text { Peringkat } \\
\text { Aroma }\end{array}$ & $\begin{array}{c}\text { Peringkat } \\
\text { Rasa }\end{array}$ & $\begin{array}{c}\text { Peringkat } \\
\text { Tekstur }\end{array}$ & $\begin{array}{c}\text { Peringkat } \\
\text { Overall } \\
\text { Liking }\end{array}$ \\
\hline \multirow{3}{*}{ Tuban } & $1: 1$ & 6.76 & 5.49 & 5.47 & 5.91 & 5.88 \\
& $2: 1$ & 5.16 & 4.30 & 3.81 & 4.07 & 3.79 \\
& $3: 1$ & 6.08 & 6.08 & 4.72 & 4.18 & 4.62 \\
Sudan & $1: 1$ & 5.92 & 4.72 & 6.09 & 6.14 & 6.11 \\
& $2: 1$ & 5.05 & 5.38 & 5.68 & 4.27 & 5.31 \\
& $3: 1$ & 4.72 & 5.00 & 4.21 & 4.05 & 3.96 \\
Gajah & $1: 1$ & 4.76 & 5.46 & 5.55 & 5.90 & 5.81 \\
& $2: 1$ & 4.35 & 5.49 & 4.84 & 5.68 & 5.24 \\
& $3: 1$ & 2.20 & 4.09 & 4.64 & 4.80 & 4.29 \\
\hline
\end{tabular}

Pada parameter rasa, peringkat tertinggi diperoleh sampel enting - enting geti dengan varietas kacang tanah Tuban dan rasio gula aren : gula pasir (1:1). Hasil menyatakan bahwa sampel ini yang paling digemari oleh panelis uji karena menghasilkan warna coklat karamel dan glossy. Pada dasarnya gula aren memiliki warna coklat kekuningan hingga coklat yang dapat dihasilkan akibat terjadinya reaksi Maillard selama proses pembuatannya (Choong et al., 2016). Selain itu proses penyangraian kacang juga dapat meningkatkan pigmen coklat akibat terjadinya reaksi pencoklatan seperti reaksi Maillard dan karamelisasi (Bagheri et al., 2019).

Pada parameter aroma, peringkat tertinggi diperoleh sampel enting - enting geti dengan varietas kacang tanah Tuban dan rasio gula aren : gula pasir (3:1). Hasil menyatakan bahwa sampel ini yang paling digemari oleh panelis uji karena menghasilkan kombinasi aroma 
khas kacang sangrai dengan manis khas gula aren. Barlina (2015) menyatakan bahwa senyawa volatil yang umumnya teridentifikasi pada gula aren adalah senyawa alkohol, keton, pirazin, asam, furan, aldehid, fenol dan ester. Senyawa volatil yang ditemukan pada kacang tanah sangrai dan berperan dalam menghasilkan aroma panggang khas kacang sangrai diantaranya adalah 2-acetyl-1-pyrroline, 2-acetylpyrazine, 2-propionyl-1-pyrroline dan 2acetyl-2-thiazoline (Chetschik et al., 2010).

Pada parameter rasa, peringkat tertinggi diperoleh sampel enting - enting geti dengan varietas kacang tanah Sudan dan rasio gula aren : gula pasir (1:1). Hasil menyatakan bahwa sampel ini yang paling digemari oleh panelis uji karena menghasilkan kombinasi rasa manis dan gurih yang cukup baik dimana tidak terdapat rasa yang terlalu mendominasi. Choong et al. (2016) menyatakan bahwa senyawa 5-hydroxymethylfurfural berperan dalam membentuk flavor seperti karamel dan gula terbakar (burnt), sedangkan 2, 3-dihydro-3, 5-dihydroxy-6methyl-4H-pyrane-4-one berperan dalam memberikan rasa astringent (sepat) pada gula aren. Senyawa pirazin pada kacang tanah sangrai dapat menghasilkan flavor panggang yang khas (roasted peanutty flavor) (Gama dan Adhikari, 2019).

Pada parameter tekstur, peringkat tertinggi diperoleh sampel enting - enting geti dengan varietas kacang tanah Sudan dan rasio gula aren : gula pasir (1:1). Hasil menyatakan bahwa sampel ini yang paling digemari oleh panelis uji karena menghasilkan tekstur yang renyah. Kombinasi gula pasir dan gula aren yang setimbang ini menghasilkan tekstur yang kokoh dan renyah karena adanya kandungan sukrosa yang lebih banyak dapat menyebabkan tekstur menjadi kompak dan kokoh (Prayogi, 2016). Bagheri et al. (2019) menyatakan bahwa proses penyangraian dapat mempengaruhi tekstur kacang tanah menjadi lebih renyah dan lebih lembut akibat dari penurunan kandungan air pada kacang tanah.

Pada parameter overall liking, peringkat tertinggi diperoleh sampel enting - enting geti dengan varietas kacang tanah Sudan dan rasio gula aren : gula pasir (1:1). Hal tersebut dikarenakan sampel ini menghasilkan produk enting-enting geti dengan penilaian secara keseluruhan terbaik. Berdasarkan kuisioner yang telah diberikan kepada seluruh panelis, sebagian besar panelis menyatakan bahwa atribut yang paling penting dalam produk entingenting geti adalah rasa disusul dengan tekstur, warna dan aroma. Sampel ini dapat dikatakan sebagai sampel yang paling disukai karena memiliki nilai yang cukup tinggi dalam atributatribut tersebut.

\section{Penentuan Perlakuan Terbaik}

Pemilihan perlakuan terbaik enting-enting geti dilakukan berdasarkan atas parameter dari produk yang diuji. Parameter yang digunakan yaitu kadar protein, kadar lemak, total gula, dan seluruh hasil organoleptik. Pemilihan parameter-parameter tersebut berdasarkan atas faktor kepentingan dan penilaian penghargaan yang terbaik. Perlakuan terbaik terdapat pada enting-enting geti dengan perlakuan varietas kacang tanah Sudan dan rasio gula aren : gula pasir (1:1). Menunjukkan bahwa enting-enting geti perlakuan terbaik memiliki daya patah $13.00 \mathrm{~N}$, nilai kecerahan $\left(\mathrm{L}^{*}\right) 70.93$, nilai kemerahan $\left(\mathrm{a}^{*}\right) 5.45$, nilai kekuningan $\left(\mathrm{b}^{*}\right)$ 26.90, kadar air $5.31 \%$, kadar protein $12.23 \%$, kadar lemak $24.83 \%$, total gula $37.85 \%$, nilai organoleptik parameter warna 6.73 , nilai organoleptik parameter aroma 6.02 , nilai organoleptik parameter rasa 6.48 , nilai organoleptik parameter tekstur 6.14 , dan nilai organoleptik parameter overall liking 6.38.

\section{SIMPULAN}

Produk enting-enting geti dengan perlakuan terbaik didapatkan pada produk entingenting geti dengan varietas kacang tanah Sudan dan rasio gula aren : gula pasir (1:1). Diperoleh produk enting-enting geti perlakuan terbaik yang memiliki kadar air $5.31 \%$, kadar protein $12.23 \%$, kadar lemak $24.83 \%$, total gula $37.85 \%$, daya patah $13.00 \mathrm{~N}$, nilai kecerahan $\left(L^{*}\right) 70.93$, nilai kemerahan $\left(a^{*}\right) 5.45$, nilai kekuningan $\left(b^{*}\right) 26.90$, nilai organoleptik untuk parameter warna, aroma, rasa, tekstur serta overall liking sebesar 6.73, 6.02, 6.48, 6.14, dan 6.38 . 


\section{DAFTAR PUSTAKA}

AACC. (2000). Approved methods of american association of cereal chemists. Minnesota: AACC International.

Abbas, Z., Kumar, A., \& Kumar, A. (2018). Peanut agriculture and production technology : Integrated nutrient management. Oakville: Apple Academic Press Inc.

Abdualrahman, M. A. Y. (2013). Chemical, in-vitro protein digestibility, minerals and amino acids composition of edible peanut seeds (Arachis hypoaea L.). Science International, $1(6), 199-202$.

Amaluddin, M. R., \& Yuwono, S. S. (2015). Pengaruh proporsi gula merah dengan kacang tanah dan penambahan terasi terhadap sifat fisiko kimia dan organoleptik bumbu rujak manis cepat saji. Jurnal Pangan dan Agroindustri, 3(2), 324 - 332.

AOAC. (2005). Official methods of analysis. Washington D.C: AOAC International.

AOAC. (2006). Official method 980.17 preservatives in ground beef spectrophotometric method. Washington D.C: AOAC International.

Apriyanto. (1994). Analisis pangan. Bogor: IPB Press.

Badan Standardisasi Nasional (BSN). (1995). Gula palma (SNI No. 01-3743-1995). Jakarta: Badan Standardisasi Nasional.

Badan Standardisasi Nasional (BSN). (1996). Enting-enting gepuk (SNI No. 01-4034-1996). Jakarta: Badan Standardisasi Nasional.

Bagheri, H., Kashaninejad, M., Ziaiifar, A., M., \& Aalami, M. (2018). Textural, color and sensory attributes of peanut kernels as affected by infrared roasting method. Information Processing in Agriculture, 6(2019), 255-264.

Balai Penelitian Tanaman Aneka Kacang dan Umbi (BALITKABI). (2016). Deskripsi varietas unggul kacang tanah (1950-2016). Diakses dari http://balitkabi.litbang.pertanian.go.id/publikasi/deskripsi-varietas/

Barlina, R. (2015). Pengaruh penyaringan nira terhadap senyawa volatil gula aren. B. Palma, 16(1), 32-39.

Bayline, J. L., Tucci, H. M., Miller D. W., Roderick, K. D., \& Brletic, P. A. (2018). Chemistry of candy: A sweet approach to teaching nonscience major. J. Chem. Educ, 95(8), 13071315.

Chetschik, I., Granvogl, M., \& Schieberle, P. (2010). Quantitation of key peanut aroma compounds in raw peanuts and pan roasted peanut meal. Aroma reconstitution and comparison with commercial peanut products. Journal of Agricultural and Food Chemistry, 58(20), 11018-11026.

Choong, C. C., Anzian, A., Che Wan Sapawi, C. W. N. S., \& Meor Hussin, A. S. (2016). Characterization of sugar from arenga pinnata and saccharum officinarum sugars. International Food Research Journal, 23(4), 1642-1652.

Dhamsaniya, N. K., Patel, N. C., \& Dabhi, M. N. (2012). Selection of groundnut variety for making a good quality peanut butter. J. Food Sci Technol, 49(1), 115-118.

Erlienawati, T. C., Suseno, T. I. P., \& Setijawati, E. (2017). Pengaruh proporsi gula pasir dan gula aren pada karakteristik creamcheese cake setelah satu minggu penyimpanan beku. Jurnal Teknologi Pangan dan Gizi, 16(2), 88-95.

Gama, A. P. \& Adhikari, K. (2019). Sensory characterization of dominant malawi peanut varieties after roasting. Journal of Food Science, 84(6), 1554-1562.

Iskandar, A., Yuliasih, I., Machfud, \& Haryanto, B. (2015). Karakteristik sifat fisiko kimia, struktur dan morfologi gula aren cetak. Jurnal Teknologi Industri Pertanian, 25(2), 107115.

Ismayasari, A. A., Wahyuningsih \& Paramita, O. (2014). Studi eksperimen pembuatan entingenting dengan bahan dasar kedelai sebagai bahan pengganti kacang tanah. Food Science and Culinary Education Journal, 3(1), 1-9.

Januariani. (2018). Tulungagung dalam rasa. Yogyakarta: Deepublish.

Makeri, M. U., Bala, S. M., \& Kassum, A. S. (2011). The effect of roasting temperatures on the rate of extraction and quality of locally-processed oil from two nigerian peanut (Arachis hypogaea L.) cultivars. African Journal of Food Science, 5(4), 194-199. 
McDaniel, K. A., White, B. L., Dean, L. L., Sanders, T. H., \& Davis, J. P. (2012). Compositional and mechanical properties of peanuts roasted to equivalent colors using different time/temperature combinations. Journal of Food Science, 0(0), C1-C7.

Mora-Escobedo, R., Hernandez-Luna, P., Joaquin-Torres, I. C., Ortiz-Moreno, A., \& RoblesRamirez, M. D. C. (2015). Physicochemical properties and fatty acid profile of eight peanut varieties grown in mexico. CyTA - Journal of Food, 13(2), 300-304.

Mustaniroh, S. A., Santoso, I., \& Permatasari, M. T. Y. K. (2019). Analisis klaster industri enting geti berdasarkan kinerja UKM dan kualitas produk menggunakan $k$-means clustering. Jurnal Teknologi Pertanian, 20(2), 103-114.

Naknean, P., \& Meenune, M. (2011). Characteristics and antioxidant activity of palm sugar syrup produced in songkhla province, southern thailand. Asian Journal of Food and Agro-Industry, 4(4), 204-212.

Prayogi, D. (2016). Sifat organoleptik hard candy susu dengan jenis gula berbeda. Jurnal Pesona, 2(1), 58-72.

Sundari, D., Almasyhuri, \& Lamid, A. (2015). Pengaruh proses pemasakan tehadap komposisi zat gizi bahan pangan sumber protein. Media Litbangkes, 25(4), 235-242.

United State Department of Agriculture (USDA). (2019). Sugar, white, granulated or lump (FDC ID 343930). Diakses dari https://fdc.nal.usda.gov/fdc-app.html\#/fooddetails/343930/nutrients

Yuwono, S., \& Susanto, T. (1998). Pengujian fisik pangan. Malang: Universitas Brawijaya.

Zeleny, M. (1982). Multiple criteria decision making. New York City: Mc Graw Hill.

Zhou, P., Guo, M., Liu, D., Liu, X., \& Labuza, T. P. (2013). Maillard-reaction-induced modification and aggregation of proteins and hardening of texture in protein bar model systems. Journal of Food Science, 78(3), C437-C444. 